\title{
Correction to: Cost-effectiveness evaluation of the 10-valent pneumococcal non-typeable Haemophilus influenzae protein D conjugate vaccine for children in Taiwan
}

\author{
Chun-Yi Lu' , Ching-Hu Chung ${ }^{2}$, Li-Min Huang ${ }^{1}$, Eliza Kruger ${ }^{3}$, Seng-Chuen Tan ${ }^{3}$, Xu-Hao Zhang ${ }^{4}$ and \\ Nan-Chang Chiu $^{2,5^{*}}$ (D)
}

\section{Correction to: Cost Eff Resour Alloc (2020) 18:30 \\ https://doi.org/10.1186/s12962-020-00225-9}

After publication of the original article [1], the authors flagged that following an update to the Markov model during the development of the manuscript (an update which resulted in modification of the estimated savings in the Results) some out-of-date values had been erroneously retained throughout figure(s) in the article. In addition to this, the related text regarding Additional file 2 had been omitted from the end of the Conclusion section.

These errors have been corrected in the original article. Please find below a summary of the errors that have been corrected:

In the Results of the Abstract:

"6.7 million" had been written instead of " 8.8 million"

"90.5\%" had been written instead of " $61 \%$ "

In Table 2, in the row 'AOM Myringotomy':

"50.92\%" had been written instead of "38.82\%"

The original article can be found online at https://doi.org/10.1186/s12962020-00225-9.

*Correspondence: ncc88@mmh.org.tw

${ }^{5}$ Mackay Children's Hospital, No. 92, Sec. 2, Zhongshan N. Rd, Taipei 10449, Taiwan

Full list of author information is available at the end of the article
In the subsection 'All-cause pneumonia effectiveness':

'23.8\%" had been given for the effectiveness estimate of PCV13 against all-cause pneumonia, while the value should read '23.7\%'.

In Table 6, in the row 'Death due to IPD/pneumonia', under columns 'PCV13 (A)' and 'PHiD-CV (B)', respectively:

"17" and "17", respectively, had been detailed instead of "19" and "19", respectively

In Table 6, in the row 'All-cause pneumonia', under the column 'Difference (B-A)':

"NTD 557 957" had been written instead of "NTD $557887 ”$

In Table 8, column 'Cost (millions)' (in descending order):

-0.6 had been written instead of -5.9

-6.6 had been written instead of -8.8

-3.9 had been written instead of -4.8

-0.8 had been written instead of -1.2

-7.1 had been written instead of -9.3

-14.4 had been written instead of -19.6

0.15 had been written instead of 5.5

-6.7 had been written instead of -8.8

-88.2 had been written instead of -90.4

c) The Author(s) 2021. This article is licensed under a Creative Commons Attribution 4.0 International License, which permits use, sharing, adaptation, distribution and reproduction in any medium or format, as long as you give appropriate credit to the original author(s) and the source, provide a link to the Creative Commons licence, and indicate if changes were made. The images or other third party material in this article are included in the article's Creative Commons licence, unless indicated otherwise in a credit line to the material. If material is not included in the article's Creative Commons licence and your intended use is not permitted by statutory regulation or exceeds the permitted use, you will need to obtain permission directly from the copyright holder. To view a copy of this licence, visit http://creativeco mmons.org/licenses/by/4.0/. The Creative Commons Public Domain Dedication waiver (http://creativecommons.org/publicdomain/ zero/1.0/) applies to the data made available in this article, unless otherwise stated in a credit line to the data. 
In Table 8, column 'QALY' (in descending order):

8 had been written instead of 14

6 had been written instead of 5

21 had been written instead of 22

38 had been written instead of 39

38 had been written instead of -12

In the Footnote of Table 8:

“- 6.7 million" had been written instead of " -8.8 million'

At the end of the 'Conclusion', the following sentence was missing:

"The supplementary Fig. 2 stresses the general context and observations that were made in the present study."

The authors apologize for any inconvenience caused.

\section{Author details}

${ }^{1}$ National Taiwan University Children's Hospital, Taipei, Taiwan. ${ }^{2}$ Mackay Medical College, Taipei, Taiwan. ${ }^{3}$ QVVIA Inc, Singapore, Singapore. ${ }^{4}$ GSK, Singapore, Singapore. ${ }^{5}$ Mackay Children's Hospital, No. 92, Sec. 2, Zhongshan N. Rd,

Taipei 10449, Taiwan

Published online: 17 May 2021

\section{Reference}

1. Lu CY, Chung CH, Huang LM, Kruger E, Tan SC, Zhang XH, Chiu NC. Costeffectiveness evaluation of the 10-valent pneumococcal non-typeable Haemophilus influenzae protein D conjugate vaccine for children in Taiwan. Cost Eff Resour Alloc. 2020;18:30. https://doi.org/10.1186/ s12962-020-00225-9.

\section{Publisher's Note}

Springer Nature remains neutral with regard to jurisdictional claims in published maps and institutional affiliations.
Ready to submit your research? Choose BMC and benefit from:

- fast, convenient online submission

- thorough peer review by experienced researchers in your field

- rapid publication on acceptance

- support for research data, including large and complex data types

- gold Open Access which fosters wider collaboration and increased citations

- maximum visibility for your research: over 100M website views per year

At BMC, research is always in progress.

Learn more biomedcentral.com/submissions 